\title{
MEAT QUALITY UNDER USE OF NATURAL FEED ADDITIVES IN YOUNG PIG FEEDING
}

S. A. TKACHUK ${ }^{1}$, Doctor of Veterinary Sciences, Professor, Department of Veterinary Hygiene named after Professor A. K. Skorokhodko https://orcid.org/0000-0002-6923-1793 ZBIGNIEW SOBEK², Doctor Habilitatus, Professor, Department of Genetics and Animal Breeding https://orcid.org/0000-0003-4115-4527

I. V. YATSENKO ${ }^{3}$, Doctor of Veterinary Sciences, Professor, Department of Veterinary Sanitary Examination and Veterinary Forensic Medicine https://orcid.org/0000-0001-8903-2129

L. V. TKACHYK ${ }^{1}$, degree seeker, Department of Veterinary Hygiene named after Professor A. K. Skorokhodko https://orcid.org/0000-0002-9136-2925

L. B. SAVCHUK 4 , Candidate of Agricultural Sciences, Associate Professor, Department of Normal and Pathological Physiology and Morphology https://orcid.org/0000-0002-5720-3533

${ }^{1}$ National University of Life and Environmental Sciences of Ukraine, 15 Heroyiv Oborony st., Kyiv 03041, Ukraine ${ }^{2}$ Poznan University of Life Sciences, Wojska Polskiego 28, 60-624 Poznań, Poland ${ }^{3}$ Kharkiv State Zooveterinary Academy, 1 Academic st., Mala Danylivka 62341, Kharkiv Oblast, Ukraine

${ }^{4}$ State Agrarian and Engineering University in Podilia, 13 Shevchenko st., Kamianets-Podilskyi 32316, Khmelnytsky region, Ukraine E-mail: ohdin@ukr.net, yacenko-1971@ukr.net, tkluz78@gmail.com, lyuba. savchuk.2015@ukr.net

Abstract. The total tasting score of meat (23.83 \pm 0.31 points) and broth (23.90 \pm 0.24 points) from the experimental group of pigs fed with $\mathrm{Lg}$-max feed additive at a dose of $2.0 \mathrm{~g} /$ day was higher than in the control (22.33 \pm 0.38 points) and meat taste in this group was significantly higher by $13.95 \%(P<0.01)$ compared with the control. In contrast, in the meat of pigs fed with Lg-max feed additive at a dose of $4.0 \mathrm{~g} /$ day, the indicator of appearance, smell and taste was significantly lower by 17.39\% ( $P<0.01), 23.40(P<0.01)$ and 13.9\% $(P<0.05)$, respectively, compared with the control. The appearance of meat from pigs fed $L g$-max $2.0 \mathrm{~g} /$ day with Sel-Plex was significantly lower by $10.87 \%(P<0.05)$ compared to the control.

According to the indicators of the tasting evaluation of the broth from the meat of pigs in the experimental groups, no statistically significant difference was found with those in the 
control, which may indicate a positive effect of the studied feed additives on the organoleptic characteristics of pork. However, the odor of the broth (in the meat of pigs fed with Lg-max feed additive at a dose of $4.0 \mathrm{~g} /$ day) was significantly lower by $20.8 \%(P<0.01)$, and the taste (meat from pigs fed with Lg-max feed additive at a dose of $2.0 \mathrm{~g} /$ day together with Sel-Plex)by $21.74 \%(P<0.05)$ compared with the control.

According to microscopic and biochemical parameters, pork from pigs of experimental and control groups met the requirements of current regulations for fresh meat obtained from healthy animals.

Keywords: pork, microscopic and biochemical parameters, tasting, Lg-max and SelPlex feed additives

\section{Introduction}

Clarification of problematic issues in modern pig farming is necessary to establish the compliance of keeping technologies with the biological characteristics of animals and the quality of food products. In addition, the obtained food products must meet the strict requirements of European legislation, and therefore it is necessary to study the quality of meat and fat products, which are produced by traditional technologies by domestic producers (Remizova, 2016).

Ensuring quality control of meat is possible through an integrated approach to this problem solving, with a comprehensive study that should be aimed at identifying organoleptic and physicochemical parameters in the food product. All indicators are defined by normative documents focused on international and European standards (Havrylenko et al., 2017).

\section{Analysis of recent researches and publications}

Pork quality is assessed by the following indicators: appearance, color, $\mathrm{pH}$, water-holding capacity, tasting parameters (Boles et al., 1998). These indicators depend on various factors: breed, feeding ration, which in turn affected the chemical composition of pork, microscopic, bio- chemical parameters, and sensory evaluation (Moeller et al., 2010; Hoa et al., 2019).

At the same time, the feeding ration is one of the main factors influencing the quality of pork. In recent years, various feed additives have been used in pork production (Han et al., 2000; Chae et al., 2002).

Currently, the main purpose of the use of various feed additives is to obtain maximum productivity, increase feed efficiency and ensure a high level of balanced feeding and improve food consumption. According to the analysis of the scientific literature, it follows that modern producers use different types of feed additives in pig feeding. Many of them are produced in the USA, England, France, and other countries and they belong to flavoring and aromatic substances, enzyme preparations, probiotics, etc.

One of the most important parameters of the nutritional value of feed is its energy level, which should not only provide physiological processes to maintain the body's vital functions, but also animal growth and development. It is known that the main energy sources are starch from cereals and fats from oilseeds. The choice of fat source for pigs is determined by the price of this raw material and in most cases very rarely pays attention to the composition of the fat source, namely, which fatty acids make up the oil or fat used in the diet. After all, fat is primarily perceived as 
a source of energy (Schönfeld et al., 2016; Zheng et al., 2021).

At the same time, preference is given to natural feed additives, in particular, research conducted over the past 5-10 years to address the issue of the optimal ratio of omega-6 to omega-3 polyunsaturated fatty acids, which is important for maintaining homeostasis of biological processes and metabolism in animals and humans and affects meat quality. Research results are in improving meat chemical composition, extension its storage time, and reducing the ratio of omega-3 to omega- 6 polyunsaturated fatty acids. It is known that the optimal ratio of Omega-3 to Omega-6 polyunsaturated fatty acids from various sources is from 1:2 to 1:4. While in the diet of most modern people this ratio is about 1:20 to 1:30 (Jaturasitha et al., 2001; Yefremov et al., 2012).

Among the essential polyunsaturated fatty acids, in particular, the family of Omega-6 or Omega-3, have the ability to counteract cardiovascular, neurodegenerative diseases, and metabolic disorders, contribute to reducing blood cholesterol. Omega-3 polyunsaturated fatty acid derivatives can act as signaling molecules by modulating the anti-inflammatory response and controlling cellular processes involved in programmed cell death (apoptosis), lymphocyte proliferation, inhibition of inflammatory cytokines, and phagocytosis. Because omega-6 polyunsaturated fatty acids are involved in the regulation of eicosanoid synthesis, they control the activity of the immune system (Gjerlaug-Enger et al., 2015; Shvediuk et al., 2017; Midyk et al., 2018).

In this scientific study, Lg-max and SelPlex feed additives were used in the feeding of young pigs. The Lg-max feed additive contains algae Schizochytrium limacinum and Rosmarinus officinalis rosemary extract and is a source for replenishment of animal omega-3 polyunsaturated fatty acids, namely docosahexaenoic acid, currently used for dogs and cats. Therefore, for the first time, our research proved the need to use Lg-max feed additive in different amounts in the main diet of fattening pigs.

In addition, the Sel-Plex feed additive, as a source for organic form of selenium, is widely used in pig feeding but mostly to improve reproductive quality. The organic form of selenium in comparison with inorganic (sodium selenite) has several significant advantages. Sel-Plex contains 1000 $\mathrm{mg} / \mathrm{kg}$ of selenium, more than $98 \%$ of which is represented by selenomethionine and selenocysteine, which are biologically active forms of this trace element found in nature (wheat, soybeans, etc.). It has a higher availability, especially under stress, and is not an oxidant, unlike selenite.

Purpose - to determine the sensory, microscopic and tasting parameters of pork after adding Lg-max and Sel-Plex feed additives to the pig diet.

\section{Materials and methods of research}

The material for the study was young pigs of meat and fat breed (Landrace $\times$ Large White) and muscle tissue samples from the longest back muscle (m. longissimus dorsi) in pigs, taken at the level of 10-12 thoracic vertebrae at slaughter at the end of the experimental period.

The experimental groups were formed from young castrated male pigs.

To conduct the experiment, after a 15 day equalization period, 4 groups of analogs by origin, age, and live weight were formed (5 animals in the control and experimental groups). There were 5 pigs in the pen (Table 1). The following periods of pig breeding are used in the experimental farm: suckling period -28 days; growing period -30-90 days; fattening - 90-180 days.

Feed additives for animals of the experimental group were administered as 


\section{Scheme of scientific experiment}

\begin{tabular}{|c|c|c|c|c|}
\hline \multirow{2}{*}{ Group of animals } & \multirow{2}{*}{$\begin{array}{c}\text { Number } \\
\text { of animals }\end{array}$} & \multicolumn{3}{|c|}{ Experimental period } \\
\hline & & equalizing & growing & fattening \\
\hline Control & 5 & \multirow{4}{*}{$\begin{array}{l}\text { Main diet } \\
\text { (MD) }\end{array}$} & MD & MD \\
\hline 1st experimental $\left(E_{1}\right)$ & 5 & & $\begin{array}{c}\mathrm{MD}+2.0 \mathrm{~g} \\
\mathrm{Lg}-\mathrm{max}\end{array}$ & $\begin{array}{c}\mathrm{MD}+2.0 \mathrm{~g} \\
\mathrm{Lg}-\mathrm{max}\end{array}$ \\
\hline 2nd experimental $\left(\mathrm{E}_{2}\right)$ & 5 & & $\begin{array}{c}\mathrm{MD}+4.0 \mathrm{~g} \\
\mathrm{Lg}-\max \end{array}$ & $\begin{array}{c}\mathrm{MD}+4.0 \mathrm{~g} \\
\mathrm{Lg}-\mathrm{max}\end{array}$ \\
\hline 3rd experimental $\left(\mathrm{E}_{3}\right)$ & 5 & & $\begin{array}{c}\mathrm{MD}+2.0 \mathrm{~g} \\
\text { Lg-max and Sel- } \\
\text { Plex }(0.5 \mathrm{mg} / \mathrm{kg})\end{array}$ & $\begin{array}{c}\mathrm{MD}+2.0 \mathrm{~g} \\
\mathrm{Lg}-\mathrm{max} \text { and Sel- } \\
\text { Plex }(0.5 \mathrm{mg} / \mathrm{kg})\end{array}$ \\
\hline
\end{tabular}

part of a premix to feed, taking into account the needs of animals in Omega-3 polyunsaturated fatty acids (daily requirement is $672 \mathrm{mg}$ ). Experimental feed additive contains $353 \mathrm{mg}$ of Omega per $1 \mathrm{~g}$.

During the entire study period, the animals were fed twice a day with dry combined fodder and water ad libitum. Feed was weighed at each feeding of the pigs, and their actual consumption was taken into account on a daily basis.

The sensory evaluation of pork was performed according to the following indicators: color, flavor, texture, condition of tendons and fat (DSTU 4823.2:2007).

The $\mathrm{pH}$ value of meat was determined by the potentiometric method using a $\mathrm{pH}$ meter-150 according to (DSTU ISO 29172001) 24 hours after the slaughter of animals.

The content of amino-ammonia nitrogen in $\mathrm{mg}$ per $10 \mathrm{~cm}^{3}$ of meat-water extract in pork was determined according to Sofronov. The content of primary degradation products of proteins in the broth was determined by the reaction with copper sulfate in the broth and the determination of volatile fatty acids by (GOST 23392-2016).

\section{Results of the research and their discussion}

Evaluation of pork quality began after slaughter by sensory evaluation of pig carcasses. The pigs were Landrace $\times$ Large White (meat and fat). Thus, the sensory evaluation confirmed the fresh degree of meat and that it was obtained from healthy animals, namely: the smell on the surface of the carcasses was pleasant, specific, the color of the meat was pale pink, the carcasses were well bled. The cut of the meat was dense, elastic; the hole formed when pressed with a spatula was quickly leveled. The muscles were slightly moist, leaving no wet spots on the filter paper. The fat was white, the texture was soft and elastic. The tendons were elastic, dense, the surface of the joints smooth.

Post-mortem inspection and trichinoscopy of the meat confirmed that the carcasses of pigs were obtained from healthy animals.

Subsequently, in order to confirm compliance with the requirements for pre-slaughter aging, the slaughter of animals and the fact that the meat is fresh and obtained from healthy pigs, laboratory studies were performed: microscopy of pork smears to determine the number of microbial cells in the field of view of the microscope ulcer tissue; reaction with copper sulfate in the broth, the essence of which is the precipitation of proteins by heating, the formation in the filtrate of complexes of copper sulfate with the products of primary decomposition of proteins 
that precipitate; the content of volatile fatty acids by a method based on the isolation of volatile fatty acids that may accumulate in the meat of sick animals, and determining their amount by titration with a solution of sodium hydroxide obtained distillate; amino-ammonia nitrogen content, which is the most characteristic and constant sign of spoilage of meat and the presence of possible diseases of pigs.

According to the research results presented in Table 2, it follows that all these indicators correspond to the regulatory documents. For some of the indicators obtained, a statistically significant difference is observed.

Microscopy of smears-imprints obtained from meat should not reveal microbial cells or there are up to 10 of them in the field of view of the microscope; by reaction with copper sulfate, the broth should be clear; content of volatile fatty acids - up to $4.0 \mathrm{mg} \mathrm{KOH}$; amino-ammonia nitrogen content - up to $1.26 \mathrm{mg}$; The $\mathrm{pH}$ of fresh meat and that obtained from healthy animals should be in the range of 5.6 to 6.2 ; reaction to peroxidase - positive.

According to the results of Kravchuk's research, the reaction with copper sulfate should be used as an additional method in the comprehensive assessment of meat quality, and the determination of volatile fatty acids - as arbitration, together with bacterioscopy of smears (Kravchuk, 2009).

Thus, microscopy of the smears did not show any traces of muscle tissue breakdown, the smears stained poorly. However, the number of microbial cells in the field of view of the microscope in $E_{2}$ and $E_{3}$ groups was significantly higher by $83.3(\mathrm{P}<0.01)$ and $80.4 \%$ $(\mathrm{P}<0.05)$, respectively, compared with the control. In the $\mathrm{E}_{1}$ group, a tendency to increase the number of microbial cells in the field of view of the microscope was found compared with the control. Thus, the pork samples from pigs in the experimental groups corresponded to fresh meat obtained from healthy animals. Although, in $\mathrm{E}_{2}$ and $\mathrm{E}_{3}$ groups, there was a significant increase in microbial cells compared to the control.

Table 2 shows that the content of volatile fatty acids in pork from pigs of the $\mathrm{E}_{2}$ and $\mathrm{E}_{3}$ groups significantly increased by $23.2(\mathrm{P}<0.05)$ and $16.8 \%$ $(\mathrm{P}<0.01)$, respectively, compared with the control. In $\mathrm{E}_{1}$ group found a tendency

\section{Microscopic and biochemical parameters of pork $(M \pm m, n=5)$}

\begin{tabular}{|l|c|c|c|c|}
\hline \multirow{2}{*}{\multicolumn{1}{c|}{ Indicator }} & \multirow{2}{*}{ Control } & \multicolumn{3}{c|}{ Experimental group } \\
\cline { 3 - 5 } & & $\mathrm{E}_{1}$ & $\mathrm{E}_{2}$ & $\mathrm{E}_{3}$ \\
\hline $\begin{array}{l}\text { Smear microscopy, the } \\
\text { number of microbial cells }\end{array}$ & $2.40 \pm 0.51$ & $2.60 \pm 0.40$ & $4.40 \pm 0.51^{* *}$ & $4.33 \pm 0.42^{*}$ \\
\hline $\begin{array}{l}\text { The content of volatile fatty } \\
\text { acids, mg KOH }\end{array}$ & $1.25 \pm 0.01$ & $1.31 \pm 0.03$ & $1.54 \pm 0.11^{*}$ & $1.46 \pm 0.05^{* *}$ \\
\hline $\begin{array}{l}\text { The content of amino- } \\
\text { ammonia nitrogen, mg }\end{array}$ & $0.80 \pm 0.07$ & $0.89 \pm 0.06$ & $1.00 \pm 0.04^{*}$ & $0.90 \pm 0.06$ \\
\hline PH value & $5.76 \pm 0.07$ & $5.78 \pm 0.08$ & $5.94 \pm 0.04$ & $5.80 \pm 0.05$ \\
\hline Reaction with copper sulfate & $\begin{array}{l}\text { the broth is } \\
\text { transparent }\end{array}$ & $\begin{array}{c}\text { the broth is } \\
\text { transparent }\end{array}$ & $\begin{array}{l}\text { the broth is } \\
\text { transparent }\end{array}$ & $\begin{array}{c}\text { the broth is } \\
\text { transparent }\end{array}$ \\
\hline Reaction to peroxidase & positive $(+)$ & positive $(+)$ & positive $(+)$ & positive $(+)$ \\
\hline
\end{tabular}

Note: $* \mathrm{P}<0.05 ; * * \mathrm{P}<0.01 ; * * * \mathrm{P}<0.001$ compared with the control of the corresponding age. 
to increase the number of microbial cells in the field of view of the microscope compared with the control. A slight increase in volatile fatty acids in the meat from pigs of the $\mathrm{E}_{2}$ and $\mathrm{E}_{3}$ may be due to an increase in microbial contamination of the carcasses, as well as an increase in the amount of subcutaneous fat.

It is known that volatile fatty acids can be formed from both lactic acid and amino acids by deamination. In addition, volatile fatty acids are formed during the breakdown of lipoids. Researchers have studied the role of volatile fatty acids in various physiological and pathophysiological conditions but some of them indicate the possibility of using volatile fatty acids as biochemical markers for diagnosing several diseases (Nezghoda et al., 2019).

One of the chemical reactions that indicates the formation of amino compounds and ammonia bases is a determination of amino-ammonia nitrogen content in pork. Thus, in the $\mathrm{E}_{2}$ group, the content of amino-ammonia nitrogen was significantly higher by $25.0 \%(\mathrm{P}<0.05)$ compared with the control. In the $\mathrm{E}_{1}$ and $\mathrm{E}_{3}$ groups, a tendency to increase volatile fatty acids was found compared with the control. It can be assumed that the amount of amino-ammonia nitrogen in pork from pigs of the experimental group that received $4.0 \mathrm{~g}$ /day of Lg-max feed additive is related to the content of volatile fatty acids and the number of microbial cells.

One of the most important factors characterizing the quality of pork is acidity $(\mathrm{pH})$. Because the concentration of hydrogen ions in meat depends on the content of glycogen and lactic acid in the muscles at the time of slaughter and, as a consequence, is a derivative of the physiological state in animals before slaughter, and reflects the course of postmortem processes in the carcass.
Closely related to this indicator are color, water-holding capacity, tenderness, and other meat quality indicators. Due to the processes of post-mortem glycolysis, the $\mathrm{pH}$ shifts to the acidic side until a final value specific to each type of meat. In pork, the final $\mathrm{pH}$ value is reached after 24 hours and is from 5.6 to 6.4 under normal conditions. The $\mathrm{pH}$ value is influenced by stressful situations that occur in animals before slaughter (predominance, transportation, physical, mental stress, high temperatures, etc.). All these factors cause stress in animals that induces increased adrenaline secretion and promotes the breakdown of glycogen in the liver (Teuteberg et al., 2021).

In addition, Kasyanchuk \& Bogatko (2017) noted that meat obtained from animals with dystrophic changes in the liver or kidneys has higher $\mathrm{pH}(6.2 \pm$ $0.1)$ than meat obtained from healthy animals (5.6-5.7). At $\mathrm{pH}$ values up to 5.4 and below, conditions are created for the survival and reproduction of gram-negative bacteria, most strains of yeast and fungi (Bohatko, 2017).

According to the reaction on determination the acidity of pork in the control and experimental groups, the $\mathrm{pH}$ value ranged from 5.76 to 5.80 , which is within the normal range for fresh meat, matured (after slaughter 24 hours) and obtained from healthy animals.

In reaction with copper sulfate, the obtained broth was transparent, indicating that when the minced meat was heated in a boiling water bath, no primary breakdown products of meat proteins (peptones, polypeptides) were formed.

The reaction on the presence of peroxidase (an enzyme of protein nature) was positive, which indicates a sufficiently high activity of this enzyme. Confirmation of a positive reaction is 


\section{Tasting evaluation of pork (cooking test), points $(M \pm m ; n=5)$}

\begin{tabular}{|l|c|c|c|c|}
\hline \multirow{2}{*}{\multicolumn{1}{c|}{ Indicator }} & \multirow{2}{*}{ Control } & \multicolumn{3}{c|}{ Experimental group } \\
\cline { 3 - 5 } & & $\mathrm{E}_{1}$ & $\mathrm{E}_{2}$ & $\mathrm{E}_{3}$ \\
\hline Appearance & $4.60 \pm 0.19$ & $4.40 \pm 0.24$ & $3.80 \pm 0.12 * *$ & $4.10 \pm 0.10^{*}$ \\
\hline Color & $4.30 \pm 0.20$ & $4.50 \pm 0.22$ & $4.30 \pm 0.12$ & $4.80 \pm 0.12$ \\
\hline Flavor & $4.70 \pm 0.20$ & $4.80 \pm 0.13$ & $3.60 \pm 0.10^{* *}$ & $4.30 \pm 0.20$ \\
\hline Taste & $4.30 \pm 0.12$ & $4.90 \pm 0.10^{* *}$ & $3.70 \pm 0.20^{*}$ & $4.50 \pm 0.16$ \\
\hline Consistence & $4.60 \pm 0.19$ & $4.80 \pm 0.20$ & $4.70 \pm 0.20$ & $4.20 \pm 0.12$ \\
\hline Succulence & $4.30 \pm 0.25$ & $4.70 \pm 0.20$ & $4.90 \pm 0.10$ & $4.20 \pm 0.12$ \\
\hline Total score & $22.33 \pm 0.38$ & $23.83 \pm 0.31$ & $20.83 \pm 1.12$ & $21.75 \pm 0.53$ \\
\hline
\end{tabular}

Note: ${ }^{*} \mathrm{P}<0.05 ;{ }^{* *} \mathrm{P}<0.01 ;{ }^{* * *} \mathrm{P}<0.001$ compared with the control of the corresponding age.

the appearance of blue-green color, which turns brown. This indicates that the peroxidase decomposes oxygen peroxide with the release of oxygen, which oxidizes benzidine. This produces para-quinone diamide, which with underoxidized benzidine gives a bluegreen compound that turns brown.

Thus, the qualitative reactions can be used to state that pig slaughtering technology is followed, as well as that the meat is obtained from healthy animals.

At the same time, we conducted a tasting evaluation of meat, which is an important indicator of its quality. In several scientific studies, meat tasting is used to possibly identify differences between species, lines and crosses, particularly in poultry (Kucheruk, 2018) and in pigs (Birta et al., 2010; Novgorodskaya, 2014).

Researchers point to differences in the sensory and tasting characteristics of pig meat after slaughter, which depend on different stress sensitivities. Meat obtained from stress-sensitive pigs has low consumer properties and autolytic processes are slower (Lykhach et al., 2016). In addition, the smallest share of stress-sensitive animals was in the group of landrace animals (Vashchenko, 2017).

Tasting evaluation of meat (from the longest back muscle) in pigs, as well as meat broth, was performed by a 5-point scale. The meat samples taken for tasting had the same size and temperature according to the current regulations (Table 3 ).

According to the results shown in Table 3, it follows that the appearance of pig meat from the $\mathrm{E}_{2}$ group was significantly lower by $17.39 \%(\mathrm{P}<0.01)$, and $\mathrm{E}_{3}-$ by $10.87 \%(\mathrm{P}<0.05)$, compared with the indicator in the control.

At the same time, in the $\mathrm{E}_{2}$ group, the flavor and taste indicators were significantly lower by $23.4(\mathrm{P}<0.01)$ and $13.9 \%$ ( $\mathrm{P}<0.05)$, respectively, compared to the control.

However, the meat taste index in the $\mathrm{E}_{1}$ group was significantly higher by $13.95 \%$ $(\mathrm{P}<0.01)$ compared to the control. However, for the rest of the tasting indicators of pork (in $\mathrm{E}_{1}$ group), there is a tendency to increase compared to the control.

Table 4 presents the results of the tasting evaluation of the broth. Thus, the flavor of broth in the $\mathrm{E}_{2}$ group was significantly lower by $20.8 \%(\mathrm{P}<0.01)$, and the taste in the $\mathrm{E}_{3}$ group - by $21.74 \%$ $(\mathrm{P}<0.05)$ compared with the control.

However, most of the parameters by the tasting evaluation of the broth from the meat of the experimental pigs did not have a statistically significant difference with the control, which may indicate a 
4. Tasting evaluation of pork broth, points $(M \pm m ; n=5)$

\begin{tabular}{|l|c|c|c|c|}
\hline \multirow{2}{*}{\multicolumn{1}{c|}{ Indicators }} & \multirow{2}{*}{ Control } & \multicolumn{3}{c|}{ Experimental group } \\
\cline { 3 - 5 } & & $\mathrm{E}_{1}$ & $\mathrm{E}_{2}$ & $\mathrm{E}_{3}$ \\
\hline Appearance & $4.20 \pm 0.24$ & $4.60 \pm 0.24$ & $4.80 \pm 0.20$ & $4.20 \pm 0.37$ \\
\hline Flavor & $4.80 \pm 0.20$ & $4.80 \pm 0.20$ & $3.80 \pm 0.21^{* *}$ & $4.00 \pm 0.32$ \\
\hline Taste & $4.60 \pm 0.24$ & $4.90 \pm 0.10$ & $4.60 \pm 0.25$ & $3.60 \pm 0.24^{*}$ \\
\hline Transparency & $4.20 \pm 0.37$ & $4.80 \pm 0.20$ & $4.80 \pm 0.20$ & $4.40 \pm 0.24$ \\
\hline Richness & $4.80 \pm 0.20$ & $4.80 \pm 0.12$ & $4.20 \pm 0.37$ & $4.60 \pm 0.24$ \\
\hline Total score & $22.60 \pm 0.87$ & $23.90 \pm 0.24$ & $21.40 \pm 1.12$ & $20.80 \pm 0.86$ \\
\hline
\end{tabular}

Note: ${ }^{*} \mathrm{P}<0.05 ; * * \mathrm{P}<0.01 ; * * * \mathrm{P}<0.001$ compared with the control of the corresponding age.

positive effect of the studied feed additives on the sensory characteristics of pork.

No statistically significant difference was found between the indicators of the total score, but in the $\mathrm{E}_{1}$ group this indicator was slightly higher than in the other experimental groups.

Therefore, according to the results of the tasting analysis, it can be stated that the tasting values of meat and broth from pigs in the $\mathrm{E}_{1}$ group were higher compared to control samples, apparently due to increased content of extractives and free amino acids in it under the influence of feed additives in different doses on nitrogen and lipid metabolism in the body of pigs.

Thus, according to the tasting evaluation of pork and broth, the best quality meat is obtained from pigs fed Lg-max at a dose of $2.0 \mathrm{~g} /$ day.

\section{Conclusions and future perspectives}

The total tasting score of meat (23.83 \pm 0.31 points $)$ and broth $(23.90 \pm 0.24$ points) from pigs of the experimental group fed with Lg-max feed additive at a dose of $2.0 \mathrm{~g}$ /day was higher than in the control ( $22.33 \pm 0.38$ points $)$ and the meat taste in this group was significantly higher by $13.95 \%(\mathrm{P}<0.01)$ compared with the control. In contrast, in the meat of pigs fed with Lg-max feed additive at a dose of $4.0 \mathrm{~g} /$ day, the indicator of appearance, smell and taste was significantly lower by $17.39 \%(\mathrm{P}<0.01)$, by $23.40(\mathrm{P}<0.01)$ and $13.9 \%(\mathrm{P}<0.05)$, respectively, compared with the control. The appearance of meat from pigs fed with Lg-max $2.0 \mathrm{~g}$ /day with Sel-Plex was significantly lower by $10.87 \%$ ( $\mathrm{P}<$ $0.05)$ compared to the control.

According to the indicators of the tasting evaluation of the broth from the meat of pigs in the experimental groups no statistically significant difference was found with those in the control, which may indicate a positive effect of the studied feed additives on the organoleptic characteristics of pork. However, the favor of the broth (in the meat of pigs fed with Lg-max feed additive at a dose of $4.0 \mathrm{~g}$ /day) was significantly lower by $20.8 \%(\mathrm{P}<0.01)$, and the taste (meat from pigs fed with Lgmax feed additive at a dose of $2.0 \mathrm{~g}$ /day together with Sel-Plex) - by $21.74 \%(\mathrm{P}<$ 0.05) compared with the control.

According to microscopic and biochemical parameters, pork from pigs in the experimental and control groups met the requirements of current regulations for fresh meat obtained from healthy animals. 
Further research concerns the histological examination of the liver in young pigs after the use of different amounts of feed additives.

\section{References}

Bohatko, N. M. (2006). Veterynarno-sanitarna otsinka yakosti yalovychyny NOR, PSE, DFD ta udoskonalennia metodiv vyznachennia yii svizhosti [Veterinary assessment of beef quality NOR, PSE, DFD and improvement of methods for determining its freshness]. Bila Tserkva. Boles, J. A., Mikkelsen, V. L., \& Swan, J. E. (1998). Effects of chopping time, meat source and storage temperature on the colour of New Zealand type fresh beef sausages. Meat science, 49(1), 79-88. doi: 10.1016/s0309-1740(97)00112-5.

Birta, H. O., \& Burhu, Yu. H. (2010). Smakovi vlastyvosti miasa svynei [Flavoring properties of pork]. Visnyk Poltavskoi derzhavnoi ahroranoi akademii, 3, 90-92. Retrieved from http:// nbuv.gov.ua/UJRN/nvpuettn_2018_1_16.

Chae, B. J., \& Lee, S. K. (2002). Rancid rice bran affects growth performance and pork quality in finishing pigs. Asian Australasian Journal of Animal Sciences, 15(1), 94-101. doi: 10.5713/ajas.2002.94 DSTU 4823.2:2007. (2007). Miaso. Metody vidboru prob zrazkiv ta orhanoleptychni metody kontroliuvannia svizhosti [Meat. Methods for the collection of samples of intelligence and organoleptic methods for the control of blood pressure]. Kyiv: DP "UkrNDNTs".

DSTU ISO 2917-2001. (2002). Miaso ta miasni produkty. Vyznachennia $\mathrm{pH}$ (kontrolnyi metod) [PH value (control method)]. Kyiv: DP "UkrNDNTs".

GOST 23392-2016. (2017). Myaso. Metody himicheskogo i mikroskopicheskogo analiza svezhesti myasa [Meat. Methods for chemical and microscopic analysis of meat freshness]. Moskow: Standartinform

Vashchenko, O. V. (2017). Stresochutlyvist molodniaku svynei za riznykh variantiv poiednan henotypiv zarubizhnoho pokhodzhennia ta vitchyznianoi selektsii [Stress sensitivity of young pigs in different variants of combinations of genotypes of foreign origin and domestic selection]. Molodyi vchenyi, 10(50), 85-89. Retrieved from http://molodyvcheny. in.ua/files/journal/2017/10/20.pdf.

Havrylenko, O. S., Khomitska, O. A., \& Zahorulko, O. V. (2017). Ekspertni doslidzhennia miasa ta miasnykh produktiv [Expert research of meat and meat products]. Visnyk Poltavskoi derzhavnoi ahrarnoi akademii, 1-2, 74-77. doi: 10.31210/visnyk2017.1-2.14.

Yefremov, D. V., \& Horb, S. V. (2012). Bilkovo-vitaminno-mineralni dobavky na osnovi mistsevoi kormovoi syrovyny pivdnia Ukrainy dlia porosiat na doroshchuvanni [Protein-vitamin mineral supplements based on local feed raw materials of the south of Ukraine for piglets on rearing]. Naukovyi visnyk “Askaniia-Nova”, 5(2), 230-236. Retrieved from http://nbuv.gov.ua/UJRN/ nvan_2012_5\%282\%29_33/

Zheng, Ch., Song, B., Guo, Q., Zheng, J., Li, F., Duan,Y., \& Peng, C. (2021). Alterations of the Muscular Fatty Acid Composition and Serum Metabolome in Bama Xiang MiniPigs Exposed to Dietary Beta-Hydroxy Beta-Methyl Butyrate. Animals, 11(5), 1190. doi: 10.3390/ani11051190.

Gjerlaug Enger, E., Haug, A., Gaarder, M., Ljøkjel, K., Stenseth, R. S., Sigfridson, K., ... \& Berg, P. (2015). Pig feeds rich in rapeseed products and organic selenium increased omega-3 fatty acids and selenium in pork meat and backfat. Food Science and Nutrition, 3(2), 120-128. doi: 10.1002/fsn3.182.

Han, S. K., \& Yamauchi, K. (2000). The effects of nitrite treatment on the lipid composition, fatty acid composition, and susceptibility to oxidation of pork biceps femoris muscle. Asian Australasian Journal of Animal Sciences, 13(12), 1764-1769. doi: 10.5713/ ajas.2000.1764.

Hoa, V. B., Seong, P. N., Cho, S. H., Kang, S. M., Kim, Y. S., Moon, S. S., ... \& Seol K. H. (2019). 
Quality characteristics and flavor compounds of pork meat as a function of carcass quality gradeAsian-Australas Journal Animal Science, 32(9), 1448-1457. doi: 10.5713/ ajas.18.0965.

Jaturasitha, S., Wudthithumkanaporn, Y., Rurksasen, P., \& Kreuzer, M. (2001). Enrichment of pork with Omega-3 fatty acids by tuna oil supplements: effects on performance as well as sensory, nutritional and processing properties of pork. Journal Asian Science, 15(11), 1622-1633. doi: 10.5713/ajas.2002.1622.

Kucheruk, M. D. (2018). Yakist i bezpechnist orhanichnoi kuriatyny [Quality and safety of organic chicken]. Bioresursy i pryrodokorystuvannia, 10(3-4), 211-220. doi: 10.31548/ bio2018.03.027.

Kravchuk, V. V. (2009). Kryterii otsinky yakosti miasa [Measurement criteria for meat quality]. Kyiv. Lykhach, V. Ya., Lykhach, A. V., \& Kish, S. V. (2016). Biokhimichni protsesy u miasi svynei riznoi stresochutlyvosti ta umov vyroshchuvannia [Biochemical processes in pig meat of different stress and rearing conditions]. Visnyk ahrarnoi nauky Prychornomoria, 2 (90(2)), 4-15. Retrieved from http://nbuv.gov. ua/UJRN/vanp_2016_2\%282\%29_4.

Midyk, S. V., Ushkalov, V. O., Danchuk, V. V., Sysoliatin, S. V., \& Nikitova A. P. (2018). Zhyrnokyslotnyi sklad sosysok torhivelnoi merezhi m. Kyiv [Fatty acid composition of sausages of the trade network of Kyiv]. Veterynarna biotekhnolohiia, 32(2), 373-382. doi: 10.31073/vet_biotech32(2)-46.

Ministry of Agricultural Policy of Ukraine. State Department of Veterinary Medicine. (2002). Pravyla peredzabiinoho veterynarnoho ohliadu tvaryn i veterynarno-sanitarnoi ekspertyzy miasa ta miasnykh produktiv [Rules of ante-mortem veterinary inspection of animals and veterinary-sanitary examination of meat and meat products]. Retrieved from https://zakon.rada. gov.ua/laws/show/z0524-02\#Text.

Moeller, S. J., Miller, R. K., \& Edwards, K. K. (2010). Consumer perceptions of pork eat- ing quality as affected by pork quality attributes and end-point cooked temperature. Meat Science, 84, 14-22. doi: 10.1016/j. meatsci.2009.06.023.

Nezghoda, I. I., Naumenko, O. M., \& Nikulchenko, O. V. (2019). Letki zhyrni kysloty yak metabolichni markery porushennia mikrobiotsenozu kyshechnyku pry rotavirusnii infektsii u ditei [Volatile fatty acids as metabolic markers of intestinal microbiocenosis in rotavirus infection in children]. Infektsiini khvoroby, 3, 24-32. doi: 10.11603/16812727.2019.3.10632.

Novhorodska, N. V. (2014). Otsinka yakosti svynyny [Evaluation of pork quality]. Naukovyi visnyk Lvivskoho natsionalnoho universytetu veterynarnoi medytsyny ta biotekhnolohii im. Gzhytskoho, 16(2(3)), 305-309. Retrieved from http://nbuv.gov. ua/UJRN/nvlnu2014162\%283\%2948.

Pro osnovni pryntsypy ta vymohy do bezpechnosti ta yakosti kharchovykh produktiv [On the basic principles and requirements for food safety and quality]: Zakon Ukrainy № 1602-VII. (2014)

Remizova, O. (2016). Vady miasa svynyny za dii pryzhyttievoho tekhnolohichnoho temperaturnoho stresu [Defects of pork meat under the influence of lifelong technological temperature stress]. Naukovi dopovidi NUBiP Ukrainy, 4(61). doi: 10.31548/dopovidi2016.04.020.

Schönfeld, P., \& Wojtczak, L. (2016). Short and medium-chain fatty acids in energy metabolism: the cellular perspective. Journal Lipid Research, 57(6), 943-954. doi: 10.1194/ jlr.R067629.

Teuteberg,V., Kluth, I.-K., Ploetz, M., \& Krischek, C. (2021). Effects of duration and temperature of frozen storage on the quality and food safety characteristics of pork after thawing and after storage under modified atmosphere. Meat Science, 174, 108-132. doi: 10.1016/j. meatsci.2020.108419

Tkachyk, L. V., \& Tkachuk, S. A. (2015). Aktualnist zastosuvannia kormovykh dobavok na 
osnovi Omeha-3 zhyrnykh kyslot u ratsionakh hodivli svynei [The relevance of the use of feed additives based on Omega-3 fatty acids in the diets of pigs]. Naukovyi visnyk Natsionalnoho universytetu bioresursiv i pryrodokorystuvannia Ukrainy, 221, 139145. Retrieved from http://nbuv.gov.ua/ UJRN/nvnau_vet_2015_221_29.

Tofan, N. I. (2015). Dynamika pryrostiv zhyvoi masy svynei ta konversiia kormu za zghodovuvannia aminokyslotnoi kormovoi dobavky [Dynamics of live weight gain of pigs and feed conversion by feeding ami- no acid feed additives]. Visnyk ahrarnoi nauky Prychornomoria, 2(2), 205-210. Retrieved from http://nbuv.gov.ua/UJRN/ vanp_2015_2\%282\%29_35.

Shvediuk, D. A., Pasichnyi, V. M., \& Radziievska, I. H. (2017). Vplyv modyfikovanykh zhyriv na pokaznyky biolohichnoi efektyvnosti napivfabrykativ z miasa ptytsi [Infusion of modified fats on indicators of biological efficiency of food from poultry meat]. Ahrarna nauka ta kharchovi tekhnolohii, 3(97), 249250. Retrieved from http://dspace.nuft.edu. ua/jspui/handle/123456789/26988.

\section{С. А. Ткачук, З. Собек, І. В. Яченко, Л. В. Ткачик, Л. Б. Савчук (2021). ЯКІСТЬ М'ЯСА ЗА ЗАСТОСУВАННЯ У ГОДІВЛІ МОЛОДНЯКУ СВИНЕЙ НАТУРАЛЬНИХ КОРМОВИХ ДОБАВОК. Ukrainian Journal of Veterinary Sciences, 12(2): 15-25, https://doi.org/10.31548/ujvs2021.02.002}

Анотація. Загальна дегустаційна оцінка м'яса (23,83 \pm 0,31 балів) і бульйону (23,90 \pm 0,24 балів) від свиней дослідної групи, яким згодовували кормову добавку Lg-тах

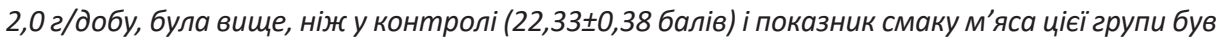
достовірно більшим на 13,95\% ( $(<0,01)$, порівнюючи з показником у контролі. Натомість, у м'ясі свиней, яким згодовували кормову добавку Lg-тах 4,0 г/добу, показник зовнішнього вигляду, запаху та смаку був достовірно меншим відповідно на 17,39\% ( $P<0,01), 23,40 \%$ $(P<0,01)$ і 13,9\% $(P<0,05)$, порівнюючи з контролем. Показник зовнішнього вигляду м'яса свиней, яким згодовували кормову добавку Lg-max 2,0 г/добу разом із Сел-Плексом був достовірно меншим на 10,87\% ( $P<0,05)$, ніж у контролі.

За показниками дегустаційної оцінки бульйону з м'яса свиней дослідних груп не встановили статистично значущої різниці із такими в контролі, що може свідчити про позитивний вплив досліджуваних кормових добавок на органолептичні показники свинини. Однак, показник запаху бульйону (у м'ясі групи свиней, яким згодовували кормову добавку Lg-max 4,0 г/добу) був достовірно меншим на 20,8\% ( $>$ < 0,01), а смаку (у м'ясі свиней, яким згодовували кормову добавку Lg-max 2,0 г/добу разом із Сел-Плекс) - на 21,74\% (P < 0,05), порівнюючи з показниками в контролі.

За мікроскопічними й біохімічними показниками свинина від свиней дослідних і контрольної груп відповідала вимогам чинних нормативних документів щодо свіжого м'яса, отриманого від здорових тварин.

Ключові слова: свинина, мікроскопічні та біохімічні показники, дегустація, кормові добавки Lg-тах і Сел-Плекс 